\title{
Era Masyarakat Informasi sebagai Dampak Media Baru
}

\author{
Astrid Faidlatul Habibah ${ }^{1}$, Irwansyah ${ }^{2}$ \\ ${ }^{1}$ Fakultas Ilmu Sosial dan Ilmu Politik, Universitas Indonesia, Astrid.faidlatul@ui.ac.id \\ ${ }^{2}$ Fakultas Ilmu Sosial dan Ilmu Politik, Universitas Indonesia, irwansyah09@ui.ac.id
}

\begin{abstract}
Abstrak
Perkembangan teknologi digital memberi pengaruh terhadap perubahan pola komunikasi masyarakat karena mampu menciptakan medium baru bagi masifikasi informasi. Media baru sebagai bagian dari hasil pengembangan kemajuan teknologi ini menggeser pola gaya hidup masyarakat yang kini beralih ke serba digital termasuk dalam menngonsumsi informasi. Arus informasi yang sangat deras melalui media baru sebagai medium membuat masyarakat kini masuk ke dalam era masyarakat informasi. Masifikasi informasi dan masyarakat informasi ini tidak terlepas dari adanya infrastruktur digital atau Information and Communication Technology (ICT) sehingga pemerintah pun terus melakukan penyediaan akses bagi seluruh masyarakat. Akses yang memadai terhadap informasi pada akhirnya meningkatkan peran masyarakat dalam membuat perubahan seiring dengan adanya peluang yang sangat luas dalam melakukan komunikasi umpan balik
\end{abstract}

Kata kunci: masyarakat informasi, teknologi digital, teknologi informasi, teknologi komunikasi

\section{Abstract}

The development of digital technology has an influence on changes in people's communication patterns because they are able to create a new medium for information massification. The new media, which is the result of the development of technological advances, shifts the lifestyle of people who switch to all digital, including in consuming information. The rapid flow of information through new media as a medium has made people enter the era of the information society. The massification of information and the information society cannot be separated from the existence of digital infrastructure or Information and Communication Technology (ICT) so that the government continues to provide access for the entire community. Adequate access to information ultimately increases the community's role in making changes along with the vast opportunities for feedback communication.

Keywords: information society, digital technology, information technology, communication technology

\section{PENDAHULUAN}

Perkembangan teknologi dan informasi menjadi sebuah reformasi yang tidak terhindarkan dalam memasuki era 4.0. Berbagai inovasi mendorong terciptanya teknologi informasi yang bersifat cepat dan kompleks namun praktis. Seluruh lapisan masyarakat pun dituntut untuk mampu mengadopsi inovasi ini seiring sifatnya yang mampu mempermudah dan membantu meringankan berbagai aktivitas kehidupan sehari-hari. Adopsi inovasi merupakan proses implementasi terhadap peradaban teknologi dengan mempertimbangkan ada atau tidaknya manfaat di dalamnya (Rogers, 1983).

Tingkat adopsi inovasi teknologi oleh masyarakat mendorong adanya persiapan infrastruktur yang matang dalam rangka memenuhi kebutuhan layanan bagi 
seluruh masyarakat terutama di Indonesia mengingat daerah-daerah di negara ini terpisah oleh pulau-pulau yang begitu luas. Sejauh ini perkembangan Information Communication Technology atau teknologi komunikasi informasi (ICT) semakin memadai meskipun untuk 122 wilayah terdepan, terpencil, dan tertinggal yang tersebar dari Sabang hingga Merauke masih membutuhkan usaha lebih ekstra.

Kementerian Komunikasi dan Informatika sendiri menyiapkan anggaran sebesar Rp22,57 triliun untuk pengembangan ICT pada 2022 mendatang. Anggaran tersebut difokuskan untuk mengakselerasi digitalisasi nasional karena masih ada sebanyak 12.548 desa dan kelurahan di Indonesia yang belum terlayani jaringan 4G. Penyediaan akses jaringan 4G nantinya akan dilakukan pemerintah terhadap 9.113 desa dan kelurahan yang masuk dalam wilayah $3 \mathrm{~T}$ sedangkan 3.435 sisanya dibangun oleh pihak swasta.

Pengembangan ICT ini sangat digencarkan oleh pemerintah mengingat teknologi sangat berpengaruh dalam kehidupan masyarakat. Indonesia harus mengikuti arus kemajuan teknologi informasi seiring negara-negara lain juga memprioritaskannya sebagai bagian dari pemberian hak bagi masyarakat. Hal ini terjadi karena teknologi juga sangat berpengaruh terhadap arus perkembangan informasi baik dari sisi produksi, konsumsi, dan distribusi.

Arus informasi menjadi sangat masif sehingga keberadaan teknologi menjadi wadah tersendiri bagi masyarakat dalam memenuhi haknya yakni memperoleh akses untuk berkomunikasi yang tidak dibatasi oleh ruang dan waktu. Bentuk dari perkembangan teknologi yaitu internet mampu meruntuhkan batasanbatasan yang selama ini menghalangi masyarakat dalam mengakses informasi maupun berkomunikasi.

Tom Kelleher mengartikan internet sebagai suatu sistem jaringan yang mampu menghubungkan berbagai perangkat teknologi seperti komputer, kabel, dan nirkabel secara global sehingga data berupa gambar, teks, video, maupun audio dapat diakses oleh seluruh masyarakat global sebagai bagian dari pertukaran informasi (Kelleher, 2007).

Internet terus berkembang sampai akhirnya melahirkan adanya media baru atau new media yang merujuk pada penekanan bentuk dan konteks budaya dalam teknologi komputer (Dewdney \& Ride, 2006). Proses produksi, distribusi, dan penggunaan media yang tidak terlepas dari aspek digitality, interactivity, hypertextuality, dan virtuality merupakan bentuk new media (Lister, 2003). Aspek digitality melingkupi seluruh proses media digital yang disimpan ke dalam bilangan sehingga hasilnya atau out put akan berbentuk online, digital disk atau memory drives yang kemudian ditampilkan oleh layar monitor berbentuk hard copy.

Interactivity merupakan aspek yang dapat memberikan kesempatan pada user untuk write back in to the text sehingga pengguna tidak menerima informasi atau data secara mentah melainkan bisa memodifikasinya. Sementara aspek dispersal media baru mengarah pada proses produksi dan distribusi media yang tersentralisasi dengan keaktifan pengguna menjadi alat dalam mengoperasikannya.

New media ini berbeda dengan digital media yang merupakan kebebasan teknologi sebagai medium karena media baru bersifat lebih kompleks dengan mengedepankan konteks dan konsep budaya kontemporer dari fungsi perangkat teknologi sebagai medium. Perkembangan 
new media yang begitu kompleks pada akhirnya menciptakan teknologi baru yakni Web 2.0. Teknologi baru yang salah satunya berupa media sosial tersebut dapat membuat pengguna secara bebas menghendaki lawan komunikasinya tanpa terbatas oleh waktu dan ruang.

Arah arus informasi juga berubah seiring terciptanya media baru. Di Indonesia perubahan arus informasi dapat dilihat antara saat masa orde baru dan masa reformasi. Informasi yang diperoleh masyarakat saat masa orde baru yaitu sekitar (1966-1998) hanya tersalurkan melalui saluran-saluran tertentu salah satunya TVRI. Hal ini terjadi karena pemerintah memasung dan membatasi kebebasan arus informasi. Sementara akses terhadap informasi pada era reformasi sangat tidak terbatas seiring mediumnya yang terbuka bebas.

Hal ini menunjukkan bahwa peradaban manusia termasuk era masyarakat informasi akan berpengaruh terhadap konsep media yang mendorong masifikasi informasi (Aoyama \& Castells, 2002). Peradaban manusia yang semakin mengadopsi teknologi serta infrastruktur yang memadai memicu terciptanya berbagai bentuk media baru termasuk dalam media massa sehingga membuat masyarakat tidak bisa terlepas dari masifnya arus informasi.

Fenomena ini disebut sebagai masyarakat informasi yaitu gambaran individu-individu yang bergantung pada keberadaan kompleksitas informasi berbasis elektronik dan digital dalam aktivitas komunikasi (McQuail, 2011). Marshal McLuhan sudah memprediksikan kemunculan masyarakat informasi ini dengan menyebutnya sebagai global village yaitu era keleluasaan memperoleh informasi secara global dengan akses yang lebih mudah dan cepat sehingga sangat berbeda jika dibandingkan dengan era masyarakat industri pada abad ke-19 dan ke-20.

Masyarakat informasi ini sebagai dampak tak terpisahkan dari ekspansi teknologi di seluruh dunia termasuk Indonesia sesuai konsep McLuhan yaitu medium is the message yang dalam hal ini berarti kemajuan teknologi merupakan medium baru dalam menciptakan new media. Adanya perkembangan teknologi membuat media menjadi berkembang sehingga menggeser subjek komunikasi pasif menjadi interaktif.

Pola interaksi dan komunikasi masyarakat saat ini terpenuhi dan terbentuk melalui media baru yang mampu menciptakan ruang bagi masyarakat untuk bebas berimajinasi hingga berpendapat bahkan jika dikaitkan dengan konteks media jaringan maka akan terbentuk cybercommunity atau komunitas cyber. Komunitas cyber tersebut mampu mendorong terciptanya interaksi dan komunikasi yang lebih luas dan tak terbatas sekaligus transparan (Bungin, 2008).

\section{KAJIAN PUSTAKA}

\section{Teknologi Komunikasi}

Teknologi komunikasi

merupakan sekumpulan perangkat teknologi yang meliputi hardware dan software hingga proses maupun sistem dengan fungsi membantu terjadinya proses komunikasi menjadi komunikatif. Komunikasi dalam hal ini adalah proses penyampaian pesan yakni ide dan gagasan yang dilakukan antara sender dan receiver sehingga dapat saling mempengaruhi satu sama lain. Komunikasi dapat dilakukan dalam bentuk lisan atau verbal maupun non verbal seperti menggelengkan kepala, 
tersenyum, mengangguk hingga menggunakan emoticon.

Teknologi komunikasi menjadi sorotan tersendiri oleh beberapa ahli seperti Everett $M$ Rogers yang menyatakan teknologi komunikasi adalah sebuah perangkat keras dengan aspek-aspek sosial dalam suatu jaringan organisasi yang mampu membuat individu-individu mengumpulkan dan memproses sekaligus bertukar informasi dengan individu lainnya (Rogers E. M., 1986).

Berdasarkan pendapat Rogers tersebut maka dapat diketahui bahwa teknologi komunikasi meliputi beberapa karakteristik yaitu berkaitan dengan perangkat keras dan muncul dalam segala aspek kehidupan masyarakat seperti sosial ekonomi, budaya hingga politik. Teknologi komunikasi juga mengandung nilainilai tertentu dari struktur yang menjadi wadah berkembangnya inovasi sekaligus berhubungan dengan perangkat keras di bidang komunikasi.

Rogers menambahkan bahwa melalui adanya perangkat keras dalam teknologi komunikasi maka pengguna dapat melakukan beberapa hal seperti demasifikasi untuk mengontrol pesan, menyesuaikan diri berdasarkan standar teknis pemakaiannya maupun meningkatkan intensitas interaksi antarindividu tanpa menghiraukan adanya hambatan jarak, waktu, dan ruang. Dalam hal ini demasifikasi sendiri merupakan sebuah perubahaan dari penggunaan teknologi komunikasi yang awalnya dilakukan secara massal atau massification menjadi secara individual.

Tak hanya Rogers, Mc Omber dalam Novi Kurnia (Kurnia, 2005) turut memberikan penilaian terhadap perkembangan teknologi komunikasi yaitu melalui sudut pandang aspek budaya. Teknologi komunikasi dianggap sebagai faktor yang berkuasa dalam kehidupan masyarakat independen dan mampu menciptakan sebuah perubahan. Teknologi komunikasi juga merupakan bentuk dari produk industrialisasi yang diciptakan dalam jumlah banyak sehingga mampu mempengaruhi maupun menggeser atau menciptakan budaya baru di tengah masyarakat.

Pergeseran budaya tersebut terjadi karena perkembangan teknologi komunikasi mampu menghasilkan alat baru yang tidak semua individu mengenalnya dengan baik sehingga memunculkan rasa penasaran yang kuat untuk mencoba atau mengaplikasikan inovasi ini. Pada akhirnya inovasi teknologi komunikasi menjadi kekuatan yang saling mempengaruhi di tengah masyarakat. Di sisi lain kekuatan saling mempengaruhi antara teknologi komunikasi dengan kekuatan sosial masyarakat tersebut tidak dapat diperkirakan secara tepat.

\section{Teknologi Informasi}

Kata teknologi dalam bahasa Yunani terdiri atas techne atau keahlian dan logia atau pengetahuan sehingga dalam hal ini teknologi mengacu pada objek benda berupa perangkat keras yang dapat memudahkan aktivitas masyarakat (Rusman, 2012). Definisi teknologi menjadi semakin kompleks seiring kemajuan zaman karena saat ini teknologi dikaitkan dengan pengetahuan mengenai penggunaan alat sehingga dapat berpengaruh pada kendali manusia dalam mengubah sesuatu yang sudah ada.

Sementara itu informasi merupakan sebuah rekaman terhadap fenomena yang terjadi (Sutopo, 2012). Informasi memiliki ciri-ciri tersendiri agar dapat 
dikatakan sebagai informasi yang berkualitas yaitu memiliki keakuratan atau mampu menggambarkan situasi yang terjadi secara nyata dan sama. Sifat informasi yang berkualitas juga harus tepat waktu atau tersedia saat diperlukan. Relevansi dan kelengkapan informasi turut dipertimbangkan yaitu harus disebarkan secara utuh dan sesuai kebutuhan.

Informasi sendiri terdiri dari beberapa jenis yaitu absolute information, substitutional information, philosophic information, subjective information, dan cultural information. Absolute information merupakan informasi yang tersaji dengan suatu jaminan karena berisi kenyataan sehingga tidak membutuhkan konfirmasi lebih lanjut. Substitutional information merupakan informasi inti yang menjadi rujukan bagi informasi-informasi lainnya. Philosophic information adalah informasi yang berisi pengetahuan tentang berbagai hal dan kebijakankebijakan.

Subjective information merupakan informasi yang berkaitan dengan perasaan atau sisi emosional dari individu sedangkan objective information adalah informasi yang mengarah pada karakter informasi tertentu. Kemudian cultural information merupakan informasi yang mampu memberikan pengaruh atau tekanan terhadap suatu budaya masyarakat.

Secara umum teknologi informasi digunakan untuk mengelola, memproses, mendapat menyusun, menyimpan hingga memanipulasi data dalam rangka menghasilkan kualitas informasi yang baik. Teknologi informasi ini sering digunakan pada seluruh aspek kehidupan masyarakat termasuk pemerintahan dalam membuat suatu kebijakan atau pengambilan keputusan.

Menurut Richard Weiner, teknologi informasi adalah kombinasi komputer dan telekomunikasi dalam memproses, mengolah, dan menyebarkan data (Sa'ud, 2008). Teknologi informasi dalam hal ini dapat didefinisikan sebagai serangkaian proses dalam menangani informasi dengan meliputi sumber-sumber, saluran atau jaringan, hingga penerimaan informasi itu sendiri.

\section{Masyarakat Informasi}

Kemajuan teknologi dan
komunikasi berdampak pada
terciptanya arus informasi yang lebih
deras sehingga masyarakat yang dalam
hal ini sebagai subjek dari
perkembangan zaman pun turut
terpengaruh. Masyarakat global
termasuk Indonesia kini semakin aktif
dalam mengaplikasikan perkembangan
teknologi komunikasi dan informasi
tersebut hingga saat ini pun masuk
dalam era masyarakat informasi.

Era yang sebenarnya telah ada sejak tahun 1970-an ini mendorong masyarakat untuk menjadikan teknologi sebagai komoditas yang harus selalu dalam pemenuhan berbagai kebutuhan kehidupan sehari-hari khususnya terhadap akses informasi. Masyarakat informasi sangat berkaitan dengan fenomena di masyarakat yang berhubungan erat dengan memperlakukan, menghargai, hingga mencari informasi.

William Martin (1995) dalam Transisi Masyarakat Indonesia Menuju Masyarakat Informasi oleh Rhoni Rodin mengatakan bahwa masyarakat informasi memiliki kualitas hidup, perubahan sosial, dan perekonomian 
yang bergantung pada peningkatan serta pemanfaatan informasi. Masyarakat informasi mampu memanfaatkan prospek terbaik dalam perkembangan informasi dan teknologi komunikasi baru atau new information and communication technologies (ICT's).

Masyarakat informasi akan mendapatkan banyak dampak positif terhadap keberadaan perkembangan teknologi komunikasi dan informasi hampir di seluruh aspek kegiatannya mulai dari bidang pekerjaan, pendidikan, sistem pemerintahan, hingga hal sederhana seperti di rumah dan tempat bermain. Spatsial menyatakan terdapat unsur-unsur tertentu agar suatu masyarakat dapat dikatakan sebagai masyarakat informasi yaitu informasi menjadi sumber utama yang dapat mempengaruhi perekonomiannya serta adanya teknologi komunikasi dan komputer sehingga informasi dapat diproses dan disebarkan.

Masyarakat informasi juga memiliki pertumbuhan informatisasi ekonomi sehingga memudahkan dalam mengintegrasikan perekonomian secara nasional maupun regional. Beberapa unsur tersebut menunjukkan bahwa masyarakat informasi sangat dekat dengan infrastruktur informasi karena seluruh aspek kehidupan mereka selalu memanfaatkan adanya peluangpeluang dalam teknologi informasi.

Masyarakat informasi mengolah seluruh proses informasi mulai dari produksi, distribusi, hingga memanipulasi sehingga taraf hidupnya seperti pendidikan, pola kerja, sekaligus pemilihan hiburan akan dipengaruhi oleh peningkatan komunikasi. Masyarakat informasi memiliki kebutuhan akan intensitas informasi yang tinggi sehingga komponen pendukung seperti teknologi informasi melengkapi sistem kehidupan mereka.

Kemampuan pertukaran dan digital yang terjadi dalam kehidupan masyarakat informasi juga sangat cepat bahkan dalam jarak yang sangat jauh namun tidak membatasi keinginan mereka untuk mendapat akses informasi yang cukup. Sistem distribusi informasi dalam masyarakat informasi juga berubah yakni dari cetak menjadi elektronik atau digital termasuk terhadap sektor perekonomian yang bergeser dari penghasil barang ke pelayanan jasa.

Webster (1995) menambahkan, masyarakat informasi memiliki beberapa kriteria yaitu technological, economic, occupational, spatial, dan cultural. Technological berarti masyarakat informasi bergantung terhadap keberadaan inovasi teknologi. Economic berarti masyarakat informasi memiliki industri informasi dalam lima aspek yaitu pendidikan, mesin, pelayanan, dan kegiatan informasi seperti penelitian serta kegiatan sosial sekaligus media komunikasi dan pendidikan.

Occupational berarti masyarakat informasi mengalami perubahan dalam aspek ketersediaan dan kebutuhan tenaga kerja di bidang informasi. Spatial merupakan jaringan masyarakat informasi yang terhubung dengan lokasi, waktu, dan ruang. Terakhir yakni cultural adalah karakteristik masyarakat informasi yang berubah sirkulasi sosial budayanya sebagai dampak dari perkembangan informasi dari berbagai medium.

\section{Media Baru}

New media atau media baru merupakan seperangkat teknologi baru 
yang mampu memperluas penyebaran informasi bagi masyarakat. Denis McQuail menyatakan media baru terdiri dari seperangkat teknologi berupa sistem transmisi yaitu kabel dan satelit, miniaturisasi, penyimpanan, pencarian informasi, penyajian gambar dengan kombinasi gambar dan grafik, serta sistem pengendalian komputer (McQuail, 1987).

Perbedaan antara media baru dengan media lama yaitu adanya desentralisasi yaitu pemilihan informasi tidak bergantung pada komunikator. Media baru juga memiliki kemampuan tinggi karena meliputi pengantaran melalui kabel dan satelit sehingga mampu meminimalisir adanya hambatan dalam proses komunikasi yang biasanya terjadi akibat dari pemancar siaran lainnya.

Dalam media baru juga dapat terjadi interaksi timbal balik karena komunikan memiliki kesempatan untuk merespon informasi yang didapat sebagai bentuk pertukaran informasi. Hal tersebut menunjukkan bahwa media baru bersifat fleksibel karena bentuk dan isi dari informasi dapat berubah-ubah.

Hal ini sejalan dengan Rogers yang menyebutkan terdapat tiga karakter utama sebagai penanda kehadirannya teknologi komunikasi baru yakni meliputi interactivity, demassification, dan asynchronous. Interactivity adalah karakter yang menunjukkan bahwa media baru memiliki fitur untuk merespon komunikasi dari sender sehingga setiap individu berperan aktif dalam proses pertukaran informasi. Demassification merupakan karakter media baru yang bersifat massal yaitu kendali dalam sistem komunikasi bergeser dari produsen menjadi konsumen media. Asynchronous memiliki arti bahwa media baru mampu mengirimkan dan menerima pesan dalam waktu sesuai yang diinginkan peserta komunikasi (Rogers E. M., 1986).

McQuail (2011) mengelompokkan media baru ke dalam empat jenis yaitu komunikasi interpersonal, media interaktif bermain, media pencarian informasi, dan media partisipasi. Media komunikasi interpersonal terdiri atas perangkat yang lekat dengan kehidupan masyarakat dan bersifat praktis seperti handphone, e-mail, dan telefon. Media interaktif bermain meliputi perangkat yang berfungsi sebagai medium dalam mengantarkan kesenangan seperti komputer, videogame, maupun internet.

Media pencarian informasi berupa portal atau search engine dalam sebuah perangkat komputer dan jaringan nirkabel sedangkan media partisipasi kolektif memanfaatkan perkembangan teknologi berupa internet untuk menyebarluaskan informasi, pendapat, dan pengalaman sehingga memicu afeksi dan emosional.

Menurut Pavlik (1998) fungsi media baru meliputi produksi yaitu mengumpulkan dan memproses informasi dengan komputer, distribusi yakni pengiriman dan penyebaran informasi elektronik, display yaitu bermacam-macam teknologi yang digunakan untuk menampilkan informasi kepada konsumen atau audiens, serta storage yang merupakan penyimpanan informasi berformat elektronik.

Perkembangan teknologi digital mampu menggeser media tradisional menjadi media baru karena terdiri dari perangkat komputer dan jaringan nirkabel sebagai medium. Masyarakat 
pun memiliki tantangan tersendiri dalam memasuki era media baru yaitu penyebaran digital yang serba digital dengan internet, world wibe web (WWW), dan multimedia (Sugihartati, 2014).

Jenis media baru juga termasuk media sosial seperti Instagram, Facebook, Twitter, YouTube, Podcast, Vodcast, Path, Tiktok, dan sebagainya. Media baru juga dapat meliputi komputer, DVD, VCD, portable media player, smartphone, video game hingga virtual reality. Berbagai media sosial sebagai bentuk dari media baru ini membuka peluang bagi masyarakat untuk secara masif mendapatkan informasi baik dengan berbicara, berbagi, berpartisipasi maupun membentuk jejaring online.

\section{METODOLOGI}

Penelitian ini menggunakan pendekatan kualitatif dengan metode deskriptif. Penelitian dengan pendekatan kualitatif menjadikan peneliti sebagai instrumen kunci dalam menentukan, mengumpulkan, dan mengontrol data (Bungin B. , 2007). Penelitian kualitatif dilakukan dengan maksud memahami fenomena yang dialami oleh objek penelitian mulai dari perilaku, cara pandang, motivasi, persepsi, tindakan, dan sebagainya yang mampu mempengaruhi suatu peradaban.

Dalam hal ini, peneliti mencoba untuk mengetahui terbentuknya masyarakat informasi dan terjadinya masifikasi informasi sebagai dampak dari perkembangan teknologi yang pada akhirnya memunculkan adanya media baru. Peneliti akan mendeskripsikan temuan-temuan yang didukung oleh eksplorasi berbagai penelitian terdahulu dengan topik pembahasan yang sama hingga data- data tambahan organisasi maupun lembaga pemerintahan. Pada akhirnya peneliti akan menggambarkan dan meringkaskan berbagai situasi atau fenomena sosial yang terjadi di masyarakat informasi.

\section{HASIL DAN PEMBAHASAN}

\section{Media Baru sebagai Implikasi Teknologi Komunikasi}

Media baru merupakan hasil dari adanya perkembangan teknologi yang mampu memperluas penyebaran informasi dan memberi peluang lebih terhadap masyarakat untuk mengontrol masifikasi informasi tersebut. Kontrol masyarakat ini termasuk menyeleksi informasi yang sekiranya bermanfaat dan dapat diterima oleh masyarakat lain. Dalam hal ini masyarakat tidak perlu meluangkan waktu secara khusus untuk beradaptasi dengan media baru karena dapat digunakan dan diaplikasikan secara langsung mengingat teknologi digital juga sudah sangat akrab dengan kehidupan sehari-hari.

McQuail menyatakan mayoritas media baru menyediakan komunikasi dua arah sehingga terdapat sifat interaktif dalam komunikasi yang dilakukan oleh seluruh lapisan masyarakat. Hal ini dapat dilihat dalam level produser yang bisa memiliki peluang lebih luas agar produknya dikenal dan diterima masyarakat karena dapat disesuaikan dengan keinginan masyarakat. Keinginan dan harapan masyarakat terhadap suatu produk dapat disampaikan secara langsung melalui media baru karena karakternya yang bersifat interaktif.

Pada proses produksi dan distribusi juga sangat diuntungkan dengan keberadaan media baru karena tidak terhalang oleh lokasi dan waktu sehingga masifikasi informasi dalam 
jumlah besar dapat dilakukan dalam satu waktu dan dapat diterima masyarakat dengan waktu yang sudah ditargetkan. Kemudian pada level penerima maka produk atau informasi dituntut untuk selalu berinovasi dan berubah mengingat era media baru membuat berpendapat menjadi lebih bebas. Produk pun juga harus berdaarkan adanya pengetahuan dan pengalaman yang bermanfaat atau mempunyai relasi dengan keadaan masyarakat terkini.

Kemunculan media baru memberikan kesempatan bagi individu untuk mampu bermain dan berperan lebih aktif sebagai bagian dari masyarakat dan warga negara sekaligus konsumen karena media baru membuka akses bagi warga negara untuk mendapat banyak informasi politik sehingga sistem berdemokrasi pun meningkat. Meski demikian, kemunculan media baru juga meningkatkan ketimpangan atau kesenjangan informasi di antara masyarakat terutama di Indonesia mengingat infrastruktur sebagai akses media baru belum merata.

Komponen komputer sebagai medium media baru juga menimbulkan dinamika di tengah masyarakat informasi. Menurut Furness hubungan antara teknologi dan manusia yang meningkat secara intensif membawa dua pilihan yang harus dihadapi masyarakat informasi yaitu pertama adalah memanusiawikan teknologi atau mengonstruksi manusia menjadu seperti teknologi. Hal ini terjadi karena dalam era media baru hampir seluruh aspek kehidupan manusia sangat bergantung pada ketersediaan teknologi (Biocca \& Levy, 1995).

\section{Masifikasi Informasi dalam Media Baru}

Kehadiran media baru mampu melahirkan informasi bersifat digital sehingga menciptakan ruang publik yang fleksibel dan cepat. Media baru yang menggunakan internet sebagai salah satu komponen penting di dalamnya tidak hanya berperan pada proses pendistribusian pesan melainkan juga terhadap pengolahan, pertukaran hingga penyimpanan. Menurut McQuail (2011)terdapat beberapa perubahan di kehidupan masyarakat sebagai tanda hadirnya media baru yaitu digitalisasi dan konvergensi dalam media termasuk pesan, peningkatan konektivitas jaringan dan interaksi, publikasi dan khalayak yang lebih mudah beradaptasi, munculnya berbagai media sebagai medium pesan, serta peran lembaga media yang menjadi kabur.

Perubahan-perubahan tersebut menuntut adanya berbagai inovasi, keterampilan, atau perubahan oleh para kreator dalam memproduksi suatu informasi, pesan, produk, maupun konten termasuk sarana mencari informasi. Hal itu harus dilakukan karena seiring akses pengetahuan meluas maka standar masyarakat terhadap sesuatu yang dikonsumsi juga akan semakin meningkat.

Berdasarkan dari data Badan Pusat Statistik (BPS) penggunaan teknologi informasi dan komunikasi (TIK) di Indonesia dalam lima tahun terakhir mengalami lonjakan yang cukup pesat yaitu salah satunya ditunjukkan melalui jumlah penduduk Tanah Ar yang menggunakan telepon selular hingga 2019 mencapai 65,53 persen. Peningkatan juga terjadi terhadap kepemilikan komputer dan akses terhadap internet yang masing-masing mencapai 18,78 persen dan 73,75 persen.

Penggunaan internet di Indonesia turut mengalami peningkatan dalam jangka lima tahun sejak 2015 sampai 2019 yaitu dari 21,98 persen naik ke level 47,69 persen. Kemudian penduduk 
usia lima tahun ke atas yang telah mengakses internet juga meningkat sepanjang 2015 sampai 2019 yakni dari 21,98 persen menjadi 43,51 persen.

Sementara berdasarkan data dari Asosiasi Penyelenggara Jasa Internet (APJII) mencatat pengguna internet di Indonesia mencapai 196,7 juta atau 73,7 persen dari keseluruhan populasi hingga kuartal II-2020. Realisasi ini didorong oleh upaya pemerintah dalam menghadirkan infrastruktur internet cepat sehingga semakin merata dan transformasi digital terjadi secara masif .

Masifikasi internet dan digital tersebut mempengaruhi munculnya media baru sehingga arus informasi sudah tidak didominasi oleh media mainstream seperti majalah, koran, tabloid, radio, dan televisi. Bentukbentuk baru dalam medium pesan bermunculan termasuk portal berita online yang saat ini sedang menjadi rujukan utama masyarakat ketika mencari suatu informasi.

Oleh sebab itu, media massa konvensional saat ini harus segera melakukan penyesuaian terhadap perkembangan teknologi digital. Kunci agar media massa konvensional tetap dapat di tengah gempuran perkembangan teknologi adalah dengan adaptasi, kreatif, inovasi seiring kondisi masyarakat yang semakin maju dan kritis terhadap berbagai fenomena yang terjadi.

Menurut data dari Dewan Pers jumlah media massa di Indonesia hingga 2018 diperkirakan mencapai 47 ribu dengan 43 ribu di antaranya adalah media online sedangkan 2.000 sampai 3.000 sisanya adalah media konvensional seperti cetak, radio, dan televisi.

Dari data tersebut menunjukkan bahwa media online sebagai bagian dari media baru telah menguasai penyebaran informasi di masyarakat karena adanya internet sehingga masifikasi informasi dapat lebih luas dan cepat. Di tengah fenomena internet dan digital tidak dapat dicegah sebenarnya hal ini juga memiliki risiko informasi tersendiri terhadap aksesibilitas yang semakin bebas, interaktivitas, konektivitas komunikasi personal meningkat, globalitas, ekonomis, politik, hingga terkikisnya kontrol jurnalistik.

\section{Transisi Era Masyarakat Informasi}

Fenomena masyarakat informasi di Indonesia sebenarnya telah ada sejak satu dekade yang lalu karena internet dan teknologi digital sudah sejak tahun 1980-an dan semakin masif keberadaannya sejak era reformasi karena selama orde baru seluruh akses internet, digital, dan informasi berada di bawah kontrol pemerintah. Kemunculan perusahaan media massa baik konvensional maupun digital menjadi suatu hal yang tidak dapat dihindari di era globalisasi terutama sejak awal masa reformasi pada 1998.

Perkembangan teknologi digital menjadi angin segar tersendiri bagi masyarakat Indonesia terutama dalam ketersediaan informasi. Hak warga negara untuk mendapat informasi yang benar, akurat dan objektif serta kebebasan untuk menyampaikan pendapat semakin memiliki wadah hingga saat ini.

Terlebih lagi, data dari Statista yang dihimpun oleh Media Katadata mencatat Indonesia berhasil masuk ke dalam 10 negara pengguna internet terbesar secara global yakni menduduki peringkat ke-5 dengan jumlah pengguna mencapai 143,36 juta per Maret 2019. Di sisi lain, Speedtest Global Index melaporkan Indonesia 
menempati posisi ke-121 dalam peringkat kecepatan internet secara global dengan kecepatan rata-rata unduh sebesar 17.33 Mbps sedangkan kecepatan unggah hanya $12.77 \mathrm{Mbps}$.

Jumlah pengguna internet yang sangat banyak namun akses terhadap internet yang belum memadai menjadi salah satu faktor terjadinya kesenjangan informasi, disinformasi, hingga misinformasi. Hal ini terjadi mengingat tidak semua masyarakat Indonesia mendapat informasi yang sama secara utuh. Sebagai contoh, masyarakat di Jawa akan lebih terdepan dalam mendapatkan informasi melalui media baru karena perangkat digital maupun aksesnya lebih memadai dibandingkan luar Jawa bahkan mereka memiliki kesempatan besar dalam mendapat update mengenai informasi tersebut.

Penggunaan media baru oleh masyarakat informasi sangat mengandalkan ketersediaan infrastruktur teknologi informasi dan komunikasi (TIK) sedangkan Indonesia yang merupakan negara dengan beribu-ribu pulau pasti membutuhkan waktu yang tidak sebentar dalam memenuhi infrastruktur tersebut. Rogers melalui teori difusi dalam Wira Respati (2014) mengenai Transformasi Media Massa Menuju Era Masyarakat Informasi di Indonesia menuturkan perubahan dapat dilakukan oleh anggota sistem sosial dalam rentang waktu tertentu melalui saluran komunikasi tertentu.

Oleh sebab itu, pemerintah Indonesia sedang mengejar ketertinggalan infrastruktur digital atau Information and Communication Technology (ICT) ini terutama untuk lebih dari 12 ribu desa yang belum tercover koneksi ICT. Pemerintah melalui
Kementerian Keuangan pun mengalokasikan anggaran untuk 2021 sebanyak Rp413,8 triliun khusus untuk infrastruktur yang meliputi pengintegrasian pusat data nasional, menyiapkan sumber daya manusia (SDM) yang paham dan ahli di bidang Teknologi Informasi (TI), sekaligus pemenuhan satelit, fiber optic, maupun based transceiver station.

Tak hanya itu, Kementerian Keuangan turut menyiapkan anggaran mencapai Rp30 triliun yang akan dialokasikan khusus transformasi digital dalam rangka mewujudkan sistem pemerintahan dan pelayanan masyarakat yang lebih efisien dan cepat sehingga kesejahteraan juga meningkat. Dalam kondisi pandemi COVID-19 seperti saat ini, pemerintah bahkan mengalokasikan anggaran untuk ICT dan internet bagi para siswa maupun pendidik yang masuk dalam program Pemulihan Ekonomi Nasional (PEN).

Berdasarkan data dari Kementerian Koordinator Bidang Perekonomian, bantuan internet ini masuk dalam subsidi kuota program perlindungan sosial dengan pagu Rp3 triliun dan realisasi per 11 Juni 2021 sebesar Rp2,33 triliun yang diberikan kepada 27,7 juta masyarakat Indonesia meliputi Puskesmas, sekolah, madrasah, dan pesantren. Kemudian untuk kebutuhan ICT pada program prioritas yang merupakan salah satu fokus program PEN memiliki pagu sebesar Rp16,57 triliun dan telah terealisasi Rp3,09 triliun per 11 Juni 2021.

Upaya-upaya ini dilakukan karena pemerintah mengetahui bahwa kebutuhan infrastruktur digital sangat dibutuhkan di era sekarang terutama dalam masa-masa pandemi yang 
mengharuskan seluruh individu dapat beradaptasi dengan kecanggihan teknologi dan internet. Sejak pandemi COVID-19 mewabah, seluruh kehidupan masyarakat sangat bergantung pada internet dan teknologi digital mengingat kewajiban untuk mengurangi keluar rumah demi menekan angka kasus positif. Seluruh aspek mulai dari pendidikan, kesehatan, hingga siklus perekonomian bergantung pada teknologi digital sehingga masyarakat Indonesia juga semakin masuk ke dalam era masyarakat informasi.

Masyarakat dapat disebut sebagai masyarakat informasi jika memiliki ciri-ciri adanya kebutuhan akan informasi dengan intensitas tinggi dalam kehidupan sehari-hari. Selain itu, ciri-ciri lain dari masyarakat informasi juga tercermin dari penggunaan teknologi informasi dalam berbagai kegiatan seperti pendidikan dan bisnis. Masyarakat dikatakan masyarakat informasi juga dapat dilihat dari kemampuan dalam pertukaran data secara digital dapat dilalui secara cepat dengan jarak jauh. Poin ketiga tersebut yang hingga kini masih diupayakan pemerintah agar dapat lebih baik.

\section{Pergeseran Pola Komunikasi dalam Media Baru}

Perkembangan teknologi komunikasi yang semakin pesat dalam media baru memunculkan pergeseran definisi teori tentang media yang telah ada. Ward dalam (Kurnia, 2005) menyatakan selama ini teori lebih mengacu pada keberadaan dan pengaruh media sedangkan untuk proses informatisasi masih tertinggal. Sementara di media baru banyak jenis yang dapat dijadikan sebagai sumber informasi dari yang bersifat sangat masif hingga personal. Hal ini melibatkan adanya proses informatisasi yeng beda dengan audiens atau konsumen yang juga berbeda.

Perkembangan media baru yang sangat cepat dan selalu berubah juga membuat informasi di era masyarakat informasi bersifat tidak terlebih lagi dengan adanya dorongan dari kecanggihan teknologi komunikasi. McQuail (2011) pun melihat terdapat permasalahan yang berbeda antara media lama dan media baru dilihat dari tiga aspek yaitu power and inequality, social integration and identity, dan social change.

Power and inequality menandakan bahwa media baru sangat sulit ditentukan kepemilikan dan kekuasaannya dari sisi isi dan arus informasi karena tidak dapat dikontrol. Social integration and identity menilai media baru memiliki kekuatan untuk disintegrasi terhadap sosial masyarakat karena sifatnya yang sangat individualistik dan tidak ada batasan antara ruang, waktu, dan budaya. Social change berarti media baru dipercaya sebagai agen perubahan terhadap sosial dan ekonomi karena adanya kontrol pesan oleh pengirim.

McQuail pun melihat adanya perubahan dan pergeseran dari pola arus informasi dalam media baru berdasarkan empat pola dasar komunikasi oleh ahli telekomunikasi Belanda yaitu J.L Bordewijk dan B. Van Kaam. Pola dasar pertama adalah Alloculation yakni pendistribusian informasi berlangsung dari pusat ke beberapa cabang. Kedua adalah conversation yakni interaksi antarindividu yang mampu memilih lawan bicara, topik, waktu, tempat, maupun tema diskusi. 
Ketiga adalah consultation yakni variasi kondisi komunikasi yang memiliki peluang untuk dilakukan secara berbeda. Keempat adalah pusat memiliki kontrol terhadap setiap individu yang berada dalam periferi atau lingkaran di sekelilingnya baik dalam hal isi maupun arah arus komunikasi yang akan dilakukan. Keempat pola tersebut saling mempengaruhi satu sama lain namun terkadang juga saling berlawanan.

McQuail sendiri telah membentuk model komunikasi dalam media baru yaitu jika dalam media lama ketersediaan sumber informasi sangat terbatas maka pada media baru memiliki sumber yang tidak terbatas. Isi informasi dalam media lama juga cenderung bersifat homogen dan kini berubah ketika media baru telah muncul yakni isi dan salurannya menjadi heterogen atau bervariasi. Kemudian jika dilihat dari sisi audiens dalam media baru telah terfragmentasi dan sangat aktif mengingat medium untuk menyalurkan pendapat sudah tersedia sangat banyak. Oleh sebab itu respon dalam media baru juga bervariasi dan tidak dapat diprediksi.

Di sisi lain, berbagai perubahan pola komunikasi tersebut tidak bersifat tetap dan akan selalu mengalami perubahan seiring perkembangan teknologi digital yang juga terus berubah sehingga memberikan pengaruh kepada terciptanya mediummedium informasi lainnya. Hal ini juga tentunya akan mempengaruhi sosial dan kebudayaan masyarakat termasuk dalam pola komunikasi.

Ini dapat dilihat dari perbedaan model komunikasi yang berlangsung dalam media lama dan baru. Model komunikasi yang digunakan dalam media lama adalah model komunikasi milik Wibur Schram yakni sourcemessage-channel-receiver (SMCR) atau bersifat linier dari sumber-pesansaluran-penerima. Di Indonesia model komunikasi ini sangat terlihat saat masih dalam orde baru di mana pemerintah memiliki kontrol penuh terhadap sumber dan arus informasi sehingga tidak ada peluang untuk terjadinya komunikasi timbal balik.

Ini menandakan media komunikasi massa di era orde baru memiliki kemampuan umpan balik yang sangat terbatas dan ketat (Straubhaar \& LaRose, 2006). Sementara dalam media baru yang terjadi setelah order baru memiliki unsur umpan balik termasuk pada media massa. Masyarakat diberikan kesempatan seluas-luasnya untuk memberikan pendapat mengenai informasi atau fenomena yang terjadi sehingga menciptakan sebuah interaktivitas. Bahkan masyarakat informasi kini juga mampu mengubah, mengontrol, dan memodifikasi isi pesan yang telah disajikan.

\section{KESIMPULAN}

Perkembangan teknologi informasi dan komunikasi telah memberi pengaruh terhadap penciptaan arus dan pola informasi dalam masyarakat. Kini masyarakat sedang dalam fase masa transisi menuju era masyarakat informasi. Pembangunan infrastruktur digital atau Information and Communication Technology (ICT) juga terus dilakukan sebagai respon dan bagian dari pemberian fasilitas bagi masyarakat untuk memenuhi haknya yaitu mendapatkan akses yang memadai terhadap informasi.

Langkah masyarakat untuk bermigrasi virtual turut memperluas peran masyarakat dalam menyuarakan berbagai perubahan mulai dari sistem 
politik, pendidikan, kesehatan maupun budaya. Hal ini terjadi karena masyarakat informasi memiliki kesempatan untuk melakukan komunikasi umpan balik yang lebih luas sehingga pesan tidak hanya diterima secara mentah melainkan dapat dimodifikasi dan dikontrol demi kepentingan bersama.

\section{References}

Aoyama, Y., \& Castells, M. (2002). An Empirical assessment of the Informational Society . International Labour Review, 141.

Biocca, F., \& Levy, M. R. (1995). Communication in the Age of Virtual Reality. New Jersey: Lawrence Erlbaum Associates.

Bungin, B. (2007). Penelitian Kualitatif. Jakarta: Kencana Prenada Media Grup.

Bungin, M. B. (2008). Konstruksi Sosial Media Massa. Jakarta: Kencana.

Dewdney, A., \& Ride, P. (2006). The New Media Handbook. London: Routledge.

Kelleher, T. (2007). Public Relations Online; Lasting concepts for changing media. USA: Sage Publications.

Kurnia, N. (2005). Perkembangan Teknologi Komunikasi dan Media Baru: Implikasi terhadap Teori Komunikasi. Media Tor, 291-296.

Lister, M. (2003). New Media : A Critical Introduction. London: Routledge.

Martin, W. (1995). The Global Information Society. England: Aslib Gower.

McQuail, D. (1987). Teori Komunikasi Massa suatu pengantar, diterjemahkan oleh Agus Dharma dan Aminuddin Ram. Jakarta: Erlangga.
McQuail, D. (2011). Teori Komunikasi Massa (ed 6). Jakarta: Salemba Humanika.

Pavlik, J. V. (1998). New Media Technology: Cultural and Commercial Perspectives. Boston: Allyn and Bacon.

Respati, W. (2014). Transformasi Media Massa Menuju Era Masyarakat Informasi di Indonesia. Binus Journal Publishing, 31-51.

Rogers, E. M. (1983). Diffusion of Innovation. New York: A Division of Macmillan Publishing Co.

Rogers, E. M. (1986). Communication Technology: The New Media in Society. New York: The Free Press.

Rusman, d. (2012). Pembelajaran Berbasis Teknologi Informasi dan Komunikasi. Jakarta: Grifindo Persada.

Sa'ud, U. S. (2008). Inovasi Pendidikan. Bandung: AlfaBeta.

Straubhaar, J., \& LaRose, R. (2006). Media Now, Understanding Media, Culture and Technology. Belmont: Thomson Wadsworth.

Sugihartati, R. (2014). Perkembangan Masyarakat Informasi dan Teori Sosial Kontemporer. Jakarta: Kencana.

Sutopo, H. (2012). Teknologi Informasi dan Komunikasi dalam Pendidikan. Yogyakarta: Graha Ilmu.

Webster, F. (1995). Theories of the Information Society. New York: Routledge. 